\title{
Cellulolytic ability of a promising Irpex lacteus (Basidiomycota: Polyporales) strain from the subtropical rainforest of Misiones province, Argentina
}

\author{
Ernesto Martín Giorgio ${ }^{1 *}$, Laura Lidia Villalba ${ }^{1}$, Gerardo Lucio Robledo ${ }^{2,3}$, Pedro Darío Zapata $^{1}$ \\ \& Mario Carlos Nazareno Saparrat ${ }^{4,5}$ \\ 1. Laboratorio de Biotecnología Molecular. Instituto de Biotecnología Misiones "Dra. María Ebe Reca". Universidad \\ Nacional de Misiones (UNaM). Ruta 12 Km 7 1/2. Campus Universitario, CP 3300. Posadas, Misiones, Argentina; \\ martingiorgio@fceqyn.unam.edu.ar, lavilla65@gmail.com,pdr.dario@gmail.com \\ 2. Laboratorio de Micología. Instituto Multidisciplinario de Biología Vegetal-CONICET. Universidad Nacional de \\ Córdoba (UNC). CC 495, CP 5000, Córdoba, Argentina; glrobledo@yahoo.com \\ 3. Fundación FungiCosmos. Av. General Paz 154, $4^{\circ}$ piso, oficina 4, Córdoba, Argentina. \\ 4. Instituto de Fisiología Vegetal (INFIVE) CCT-La Plata-Consejo Nacional de Investigaciones Científicas y Técnicas \\ (CONICET)-Universidad Nacional de La Plata (UNLP). CC 327, CP 1900, La Plata, Argentina; \\ masaparrat@yahoo.com.ar \\ 5. Instituto de Botánica Spegazzini. Facultad de Ciencias Naturales y Museo. UNLP. La Plata, Argentina. \\ * Correspondence
}

Received 29-I-2018. Corrected 11-V-2018. Accepted 13-VI-2018.

\begin{abstract}
The cellulolytic activity of fungi growing in the subtropical rainforest of Misiones (Argentina) represents a challenge in the technological development of the production of cellulosic bioethanol in the region using native sources. These fungi are promising to obtain sustainable enzyme cocktails using their enzymes. Cellulolytic ability of 22 white-rot fungi isolated from the subtropical rainforest of Misiones-Argentina in agar medium with two types of cellulosic substrates, carboxy-methylcellulose or crystalline cellulose, were comparatively analyzed, and the activity of two cellulolytic enzymes was evaluated in liquid medium. Although all isolates were able to grow and degrade both substrates in agar medium, and to produce total cellulase Filter paper (FPase) and endo- $\beta$-1,4-glucanase (EG) activities in broth, the isolate Irpex sp. LBM 034 showed the greatest enzymatic levels (FPase, $65.45 \mathrm{U} \mathrm{L}^{-1}$; EG, $221.21 \mathrm{U} \mathrm{L}^{-1}$ ). Therefore, the ITS sequence of this fungus was sequenced and analyzed through a phylogenetic analysis. These results indicate that the isolate LBM 034, corresponding to Irpex lacteus, has a promising cellulolytic ability and enzymes such as EG useful in sustainable saccharification of cellulosic materials in the region. Rev. Biol. Trop. 66(3): 1034-1045. Epub 2018 September 01.
\end{abstract}

Key words: white-rot fungi; Irpex lacteus; cellulases; FPase; endo- $\beta$-1; 4-glucanase.

Cellulose is considered to be the most abundant organic compound derived from plant biomass. Perpetual renewal of plant biomass via the process of photosynthesis ensures an inexhaustible supply of such material. The worldwide production of this biopolymer is estimated to be between $10^{10}$ and $10^{11}$ tons each year (Lynd, Weimer, van Zyl, \& Pretorius, 2002). Cellulose is a linear homopolysaccharide of $\beta$-1.4-linked anhydro-D-glucose units with a degree of polymerization of approximately 10000 for cellulose chains in nature and 15000 for native cellulose cotton (Habibi, Lucia, \& Rojas, 2010; Siqueira, Bras, \& Dufresne, 2010).

Cellulolytic enzymes degrade cellulose by cleaving the glycosidic bonds. Many fungi and bacteria are capable of producing multiple enzymes, collectively known as cellulases, that act in a synergistic manner to hydrolyze the $\beta$-1,4-D-glycosidic bonds within the cellulose molecule (Akiba, Kimura, Yamamoto, \& Kumagai, 1995). Cellulases can be classified into three types: endoglucanases 
(endo- $\beta$-1,4-glucanase, EC 3.2.1.4), cellobiohydrolases (cellulose $\beta$-1.4-cellobiosidase, EC 3.2.1.91), and $\beta$-glucosidases ( $\beta$-D-glucoside glucohydrolase, EC 3.2.1.21). Endoglucanases randomly hydrolyze internal $\beta-1,4-\mathrm{D}-$ glycosidic bonds in cellulose. As a result, the polymer rapidly decreases in length and the concentration of the reducing sugar increases slowly. Cellobiohydrolases hydrolyze cellulose by removing the cellobiose units from the nonreducing end of cellulose, and $\beta$-glucosidases, cleave glucose units from cellooligosaccharides (Siddiqui, Shemsi, Anwar, Rashid, \& Rajoka, 1999).

In Argentina, subtropical and tropical rainforests are restricted to small areas that do not reach $2 \%$ of the land area, and yet, are home to more than $50 \%$ of the biodiversity (Brown, Grau, Lomáscolo, \& Gasparri, 2002). Specifically these forests belong to two phytogeographic regions of the Amazon Domain: Yungas rainforests, located on the eastern slopes of the foothills in the Northwest of the country; and the Paranaense rainforest located in the province of Misiones and Northeast of Corrientes (Cabrera, 1994). Currently, studies of wood-decaying fungi diversity are in an active process of analysis and dissemination (Rajchenberg \& Robledo, 2013; Gallo, Robledo, Romero, \& Catania, 2014; Robledo, Giorgio, Franco, Popoff, \& Decock, 2014).

However, knowledge about the cellulolytic enzyme production of these fungi is very much restricted. The forest environments in the province of Misiones in Northeast Argentina, are a rich reservoir of biodiversity (Zuloaga, Morrone, \& Rodríguez, 1999). Exploration and description of new fungi from Paranaense rainforest can reveal innovative abilities for potential biotechnological applications such as plant biomass conversion (Saparrat, Martínez, Cabello, \& Arambarri, 2002; Giorgio et al., 2012; Daâssi et al., 2016). Moreover, the relevance of screening of new isolates in addition to culture collection strains has been already highlighted (Tekere, Mswaka, Zvauya, \& Read, 2001). In this sense, although most reports available are related to the Iguazú National Park (Wright,
Lechner, \& Popoff, 2008), there is no data for the rest of the region that remains still underexplored (Niveiro, Popoff, \& Albertó, 2010).

A high forestry activity is found in the province of Misiones-Argentina due to availability of a lot of plant sources. Therefore, there is an increase of woody wastes (Teza et al., 2012). In spite of the huge amount of this plant material, there are still burning practices for its use, however the law XVI N 106 since 2012 prohibits this activity and promotes their utilization in sustainable processes (Sistema Argentino de Información Jurídica, 2012). This has lead to the search for innovative biotechnological strategies such as the production of second generation biofuels, which is also depending upon reactive and enzymes for the process. In this sense, the availability of enzyme cocktails from autochthonous fungal sources is also a priority (King, Donnelly, Bergstrom, Walker, \& Gibson, 2008).

In the present study, we analyzed and compared the cellulolytic ability of 22 white-rot fungi, isolated from woody materials collected from the subtropical rainforest of the province of Misiones, Argentina, grown on agar medium supplemented with either sodium carboxymethylcellulose (CMC) or crystalline cellulose (CC). Furthermore, submerged cultures of these fungi in a liquid medium with $\mathrm{CMC}$ were conducted to select the isolate with the highest level of filter paper assay (FPase) and endo- $\beta$-1,4-glucanase (EG) activities, which was subsequently identified at molecular level.

\section{MATERIALS AND METHODS}

Fungal isolates: Fungal isolates from different sources were selected for this study (Table 1). They belong to the following culture collections: 1. Facultad de Ciencias Exactas y Naturales, Universidad Nacional de Buenos Aires (FCEyN-UBA); 2. Instituto Multidisciplinario de Biología Vegetal (IMBIV-CONICET) and 3. Instituto de Biotecnología Misiones, Universidad Nacional de Misiones (InBioMis$\mathrm{UNaM})$. Stock cultures of the Basidiomycetes isolates tested were kept at $4{ }^{\circ} \mathrm{C}$ on $20\left(\mathrm{~g} \mathrm{~L}^{-1}\right)$ 
TABLE 1

Fungal isolates used in this work and their source of conservation

\begin{tabular}{|c|c|}
\hline Culture Collection & Fungal isolates \\
\hline $\begin{array}{l}\text { Colección de Cultivos de Hongos, } \\
\text { Departamento de Biodiversidad y Biología Experimental, } \\
\text { FCEyN, UBA }\end{array}$ & $\begin{array}{l}\text { Coriolus versicolor (L.) Quél. BAFC } 266 \\
\text { Irpex lacteus (Fr.) Fr. BAFC } 1171 \\
\text { Lenzites elegans (Spreng.) Pat. BAFC } 2127 \\
\text { Phlebia brevispora Nakasone BAFC } 633 \\
\text { Pycnoporus sanguineus (L.) Murrill BAFC } 2126 \\
\text { Trametes villosa (Sw.) Kreisel BAFC } 2755\end{array}$ \\
\hline Laboratorio de Biotecnología Molecular, InBioMis & $\begin{array}{l}\text { Trametes sp. LBM } 029 \\
\text { Trametes sp. LBM } 030 \\
\text { Trametes sp. LBM } 031 \\
\text { Trametes sp. LBM } 033 \\
\text { Trametes villosa (Sw.) Kreisel LBM } 109 \\
\text { Trametes villosa (Sw.) Kreisel LBM } 110 \\
\text { Trametes villosa (Sw.) Kreisel LBM } 111 \\
\text { Irpex sp. LBM } 032 \\
\text { Irpex sp. LBM } 034 \\
\text { Pleurotus sajor-caju (Fr.) Singer LBM } 105 \\
\text { Pycnoporus sanguineus (L.) Murrill LBM } 106 \\
\text { Pycnoporus sanguineus (L.) Murrill LBM } 107 \\
\text { Pycnoporus sanguineus (L.) Murrill LBM } 108\end{array}$ \\
\hline Laboratorio de Micología, IMBIV-CONICET & $\begin{array}{l}\text { Perenniporia martius (Berk.) Ryvarden } \mathrm{Cu} 40 \\
\text { Perenniporia martius (Berk.) Ryvarden } \mathrm{Cu} 57 \\
\text { Perenniporia martius (Berk.) Ryvarden } \mathrm{Cu} 58\end{array}$ \\
\hline
\end{tabular}

agar slants supplemented with $12.7\left(\mathrm{~g} \mathrm{~L}^{-1}\right)$ malt extract (Saparrat et al., 2002).

Screening for fungal growth and cellulolytic ability on agar medium: Cellulolytic ability of each fungal isolate was determined by using plate screening medium containing Czapek's mineral salt solution $\left(\mathrm{NaNO}_{3} 2 \mathrm{~g}\right.$, $\mathrm{KH}_{2} \mathrm{PO}_{4} 1 \mathrm{~g}, \mathrm{KCl} 0.5 \mathrm{~g}, \mathrm{MgSO}_{4} .7 \mathrm{H}_{2} \mathrm{O} 0.5 \mathrm{~g}$, $\mathrm{FeSO}_{4} .7 \mathrm{H}_{2} \mathrm{O} 0.01 \mathrm{~g}, \mathrm{H}_{2} \mathrm{O} 1000 \mathrm{~mL}$, adjusted to $\mathrm{pH} 5.0$ with glacial acetic acid) and agar (20 $\mathrm{g} \mathrm{L}^{-1}$ ) supplemented with $1 \mathrm{~g} \mathrm{~L}^{-1}$ of CMC (Sigma-Aldrich, USA) or with $1 \mathrm{~g} \mathrm{~L}^{-1}$ of $\mathrm{CC}$ (Sigma-Aldrich, USA) as sole carbon source. Agar block (6 $\mathrm{mm}$ in diameter) from five days old fungal colony grown on MEA plates was cut and inoculated in the center of the plates. Inoculated plates were incubated at $28 \pm 2{ }^{\circ} \mathrm{C}$ for 4 days to estimate the growth extension of the colony (Guigón-López et al., 2010; Andrino, Morte, \& Honrubia, 2011) and the degradation of carbon substrate supplemented through the procedure of Mangelli \& Forchiassin (1999), calculated as the Cellulolytic Efficiency Index (CEI) according to Martínez, Chiocchio, \& Godeas (2001). All analyzes were performed in duplicate.

Fungal screening for selected cellulolytic enzymatic activities under submerged conditions: Thirty $\mathrm{mL}$ Czapek's mineral salt solution (adjusted to $\mathrm{pH}$ 5.0) supplemented with $1 \mathrm{~g} \mathrm{~L}^{-1}$ of peptone and $5 \mathrm{~g} \mathrm{~L}^{-1}$ of CMC in $250 \mathrm{~mL}$ Erlenmeyer flask was inoculated with each fungus, and incubated at $28 \pm 2{ }^{\circ} \mathrm{C}$ under static condition for 14 days. After 4, 9 and 14 days of incubation the culture medium was collected, centrifuged at $10000 \mathrm{xg}$ for $15 \mathrm{~min}$, and the clarified supernatant was used to estimate total cellulose and endo- $\beta$-1,4-glucanase activities. FPase and EG activities were determined according to Ghose (1987) using Whatman 
no.1 filter paper and CMC as substrates. The released reducing sugars were estimated as glucose by the DNS method (Miller, 1959). One unit of FPase and EG activities were defined as the amount of enzyme required to liberate $1 \mu \mathrm{mol} / \mathrm{mL}$ min of glucose from the particular substrate under the assay conditions.

Molecular identification of the fungal isolate LBM 034: DNA extractions and PCR amplifications: Genomic DNA was extracted from a three day old mycelium grown on 12.7 $\mathrm{g} \mathrm{L}^{-1}$ malt extract and corn extract $0.5 \% \mathrm{v} \mathrm{v}^{-1}$ according to Fonseca et al. (2016). PCR was performed in $20 \mu \mathrm{L}$ reactions, using 1 Unit of Taq DNA polymerase (Thermo Scientific, Fermentas), $2 \mu \mathrm{L}$ of $10 \mathrm{X}$ Taq polymerase buffer, $2 \mu \mathrm{L}$ of $25 \mathrm{mM} \mathrm{MgCl}_{2}, 1.4 \mu \mathrm{L}$ of $2.8 \mathrm{mM}$ dNTPs, $1 \mu \mathrm{L}$ of each $10 \mu \mathrm{M}$ primer and $1 \mu \mathrm{L}$ of $60 \mathrm{ng}$ template DNA. The oligonucleotide primer set ITS1 and ITS4 was used to amplify the ITS region of the rDNA (White, Bruns, Lee, \& Taylor, 1990). Amplifications were performed on a Labnet thermal cycler model MultiGene ${ }^{T M}$ II Personal Thermal Cycler using the following parameters: $4 \mathrm{~min}$ step at $94{ }^{\circ} \mathrm{C}$, followed by 35 cycles of $40 \mathrm{~s}$ at $94{ }^{\circ} \mathrm{C}, 40 \mathrm{~s}$ at $55^{\circ} \mathrm{C}$ and $40 \mathrm{~s}$ at $72{ }^{\circ} \mathrm{C}$, and a final $10 \mathrm{~min}$ extension step at $72{ }^{\circ} \mathrm{C}$.

DNA sequencing was performed on both strands in triplicate using the primers ITS1 and ITS4. Sequencing assays were analyzed on an automated DNA Sequencer ABI3730XL by Macrogen Korea. The nucleotide sequences were aligned using the Bio-Edit software.

Phylogenetic analysis: For primary sequence analyses, the software tools on the Fungal Barcoding (http://www.fungalbarcoding.org) and NCBI (http://www.nih.ncbi.gov) servers were used. The ITS sequence with the highest identity was obtained by nucleotide BLAST searches (Altschul et al., 1997). For nucleotide sequence phylogeny, maximumparsimony (MP) method was adopted. Phylogeny analysis was carried out using the T.N.T version 1.1 software (Goloboff, Farris, $\&$ Nixon, 2008). To assess the support for the identified groups, we performed a Bootstrap test. Bootstrap analyses included 1000 resampled matrices. For each resampled matrix, we performed 100 Random Addition Sequences (RAS) + Tree Bisection Reconnection (TBR) cycles. Sequences were aligned using T-Coffee Multiple Sequence Alignment. All alignment gaps were treated as missing data. The alignments were manually trimmed (overhangs were removed and gaps were corrected) prior to phylogenetic calculations. The ITS region of 5.8S ribosomal DNA sequences was submitted to GenBank (accession LN606596).

All results are shown as mean \pm standard deviation (SD). The differences in fungal growth and CEI between isolates were analyzed by a one-way analysis of variance (ANOVA) and means were contrasted by the Tukey Test, using the InfoStat version 2013 software (Grupo InfoStat, FCA, UNC, Argentina). To establish differences of extracellular total cellulase and endo- $\beta$-1,4-glucanase activities among isolates, ANOVA tests were performed.

\section{RESULTS}

Screening for fungal growth and cellulolytic ability on agar medium: Screening for fungal growth and cellulolytic ability was carried out by the hydrolysis of CMC or CC supplemented to the basal medium. All fungi showed ability to grow and degrade both substrates.

The Phlebia brevispora BAFC 633 isolate showed the fastest radial growth rate $(0.44$ $\left.\pm 0.01 \mathrm{~mm} \mathrm{~h}^{-1}, \mathrm{P}<0.05\right)$ on CMC medium, whereas Trametes sp. LBM 033, Perenniporia martius $\mathrm{Cu}$ 40, P. martius $\mathrm{Cu} 57$ and P. martius $\mathrm{Cu} 58$ isolates showed the slowest growth rate on this substrate with a value of $0.05 \pm 0.01$ to $0.10 \pm 0.004 \mathrm{~mm} \mathrm{~h}^{-1}$. The Irpex lacteus BAFC 1171, P. brevispora BAFC 633, Lenzites elegans BAFC 2127, and Trametes villosa LBM 110 isolates showed the fastest radial growth rate (between $0.39 \pm 0.01$, and $0.37 \pm 0.01, \mathrm{P}$ $>0.05$ ) on CC medium, whereas $P$. martius $\mathrm{Cu}$ 40, P. martius $\mathrm{Cu} 57$, and P. martius $\mathrm{Cu} 58$ isolates showed the lowest ability to grow on this medium $\left(0.07 \pm 0.01 \mathrm{~mm} \mathrm{~h}^{-1}\right.$, Fig. 1a). 
The Pycnoporus sanguineus BAFC 2126, Trametes sp. LBM 031, Trametes sp. LBM 033, and P. sanguineus LBM 106 isolates showed differences in their radial growth ability. They were more efficient growing on $\mathrm{CC}$ medium $(\mathrm{P}<0.05)$. On the other hand, P. brevispora BAFC 633 isolate was more efficient growing on $\mathrm{CMC}$ medium $(\mathrm{P}<0.05$, Fig. 1a).

The cellulolytic ability of all fungi isolates was obtained by calculating the CEI. Trametes sp. LBM 033 isolate showed the most efficient degradation of CMC with a CEI of $3.58 \pm 0.13$ $(\mathrm{P}<0.05$ ), followed by P. martius $\mathrm{Cu} 40$ (with a CEI of $2.15 \pm 0.015 ; \mathrm{P}<0.05), P$. martius $\mathrm{Cu} 57$, and $P$. martius $\mathrm{Cu} 58$ isolates $(1.64 \pm$ 0.09 , and $1.47 \pm 0.02, \mathrm{P}<0.05)$. CEI values lower than 1.16 were obtained for the rest of the filamentous fungi tested; BAFC 266 isolate presented the lowest CEI with a value of $0.68 \pm 0.023$.
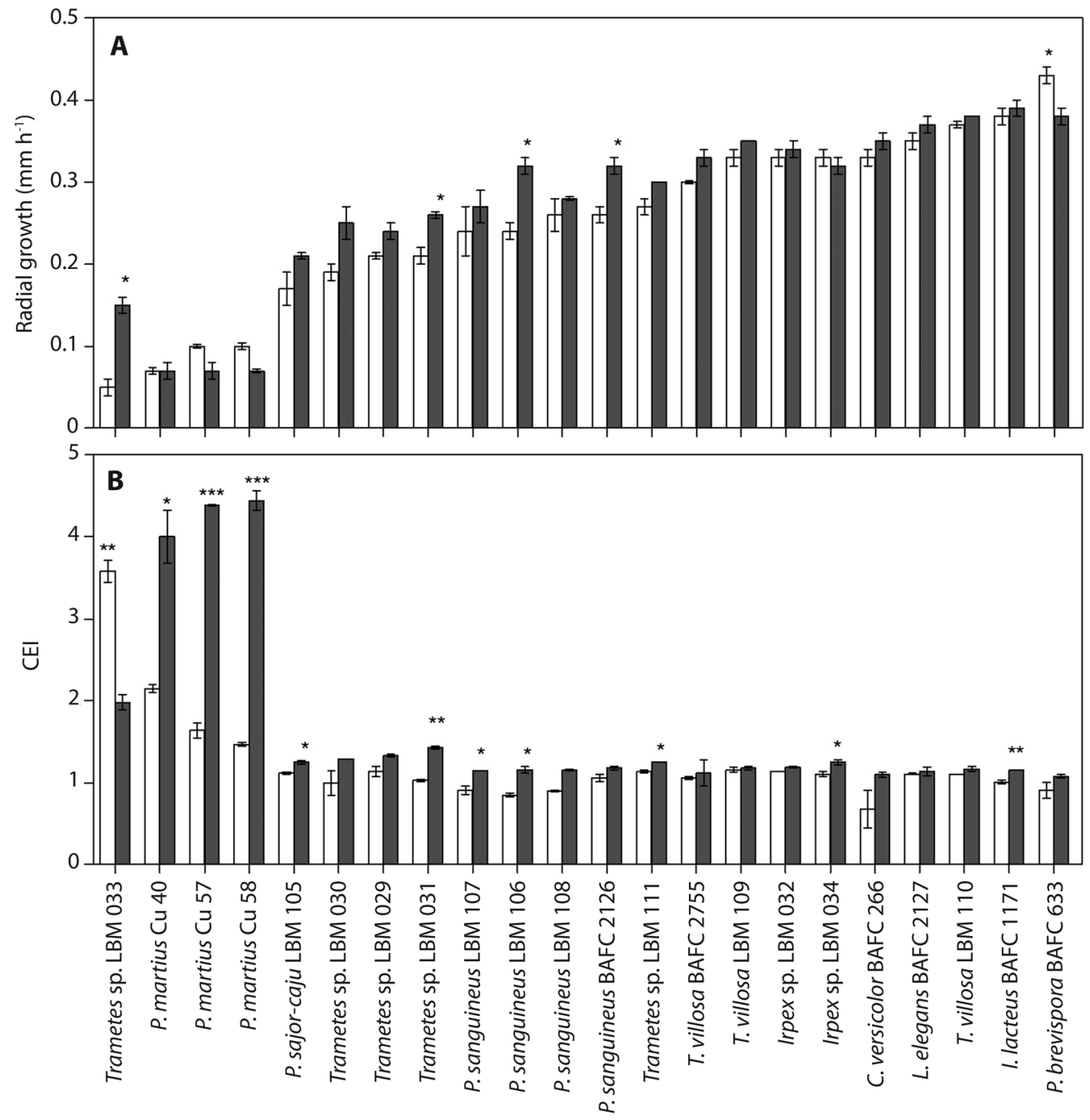

Fig. 1a. Radial growth of the colony under selective conditions in test plate. Clear ( $\square$ ), and filled ( $\square$ ) bars represent culture medium containing $\mathrm{CMC}$ and $\mathrm{CC}$, respectively. Asterisks $(*)$ denote significant differences $(\mathrm{P}<0.05$, Tukey Test $)$ in the growth extension of a given isolate on both types of substrates used. Data are mean $\pm \mathrm{SD}$ of duplicates. b. Cellulolytic Efficiency Index (CEI) of the isolates. Clear $(\square)$, and filled ( $\square$ ) bars represent culture medium containing CMC and CC, respectively. Asterisks $\left.{ }^{*}\right)$ denote significant differences $(\mathrm{P}<0.05$, Tukey test) in the CEI of a certain isolate on the two types of substrates used. Data are mean $\pm \mathrm{SD}$ of duplicates. 
Perenniporia martius $\mathrm{Cu}$ 58, and P. martius $\mathrm{Cu} 57$ isolates exhibited the most efficient degradation of CC with a CEI of $4.44 \pm 0.12$, and $4.38 \pm 0.01$, respectively. These values were followed by P. martius $\mathrm{Cu} 40$ isolate (with a CEI of $4.00 \pm 0.32 ; \mathrm{P}<0.05$, Fig. 1b). CEI values lower than 1.98 were obtained for the other filamentous fungi tested.

Pycnoporus sanguineus LBM 107, T. villosa LBM 111, P. sanguineus LBM 106, Irpex sp. LBM 034, Pleurotus sajor-caju LBM 105, and $P$. martius $\mathrm{Cu} 40$ isolates showed differences in their cellulolytic ability. They were more efficient in the degradation of the $\mathrm{CC}(\mathrm{P}<$ 0.05), while Trametes sp. LBM 033 isolate was more efficient in the degradation of the $\mathrm{CMC}$ $(\mathrm{P}<0.01$, Fig. 1b).

All isolates were selected for further studies related to cellulolytic enzymatic activities under submerged conditions.

Fungal screening for selected cellulolytic enzymatic activities under submerged conditions: At 4 days of incubation, cellulolytic activities (both FPase, and EG) were found in all the supernatants analyzed. I. lacteus BAFC 1171, P. sanguineus BAFC 2126, L. elegans BAFC 2127, P. sanguineus LBM 106, P. sanguineus LBM 107, P. sanguineus LBM 108, Trametes sp. LBM 029, Trametes sp. LBM 030, Trametes sp. LBM 031, Trametes sp. LBM 033, and Irpex sp. LBM 034 isolates presented high FPase activity (values between 33.70 and $43.73 \mathrm{U} \mathrm{L}^{-1}$ ), without significant differences $(\mathrm{P}>0.05)$.

At 9 days, $P$. brevispora BAFC 633, $P$. sanguineus BAFC 2126, P. sanguineus LBM 106, P. sanguineus LBM 107, Trametes sp. LBM 030, and Irpex sp. LBM 034 isolates presented high FPase activity (between 37.33 , and

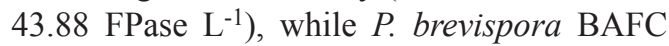
633, P. sanguineus LBM 106, and Irpex sp. LBM 034 isolates showed the highest FPase activity at 14 days of incubation (with values between 55.17, and 65.45 FPase L ${ }^{-1}$; Fig. 2a).

At 4 days of incubation, I. lacteus BAFC 1171, P. sanguineus BAFC 2126, L. elegans BAFC 2127, $P$. sanguineus LBM 106, $P$. sanguineus LBM 107, T. villosa LBM 109, T. villosa LBM 110, Trametes sp. LBM 029, Trametes sp. LBM 030, Trametes sp. LBM 031, Irpex sp. LBM 033, and Irpex sp. LBM 034 isolates showed high EG activity (values between 86.36, and $127.53 \mathrm{U} \mathrm{L}^{-1}$ ), without significant differences $(\mathrm{P}>0.05)$, and $P$. sajorcaju LBM 105, P. martius $\mathrm{Cu} 40$, P. martius $\mathrm{Cu}$ 57, and P. martius $\mathrm{Cu} 58$ isolate presented low EG activities. At 9 days, P. brevispora BAFC 633, T. villosa BAFC 2755, P. sanguineus LBM 106, P. sanguineus LBM 107, Trametes sp. LBM 030, Trametes sp. LBM 031, and Irpex sp. LBM 034 isolates showed high EG activity (values between 106.15, and $130.97 \mathrm{U} \mathrm{L}^{-1}$ ), whereas T. villosa LBM109, I. lacteus BAFC 1171, and L. elegans BAFC 2127 isolates showed low EG activity.

Finally, at 14 days of incubation Irpex sp. LBM 034 isolate presented the highest EG activity $\left(221.21 \mathrm{U} \mathrm{L}^{-1} ; \mathrm{P}<0.05\right)$ whereas $P$. brevispora BAFC 266, I. lacteus BAFC 1171, L. elegans BAFC 2127, T. villosa BAFC 2755, P. sajor-caju LBM 105, T. villosa LBM 109, T. villosa LBM 110, and Trametes sp. LBM 029 isolates showed low EG activity (Fig. 2b).

Therefore, Irpex sp. LBM 034 isolate was selected for its cellulolytic ability showing the highest values of FPase and EG activities in submerged cultures analyzed after 14 days of incubation.

Molecular identification of the fungal isolate LBM 034: Irpex sp. LBM 034, isolated from the Misiones subtropical rainforest, was selected due to its outstanding potential for EG production. It was deposited at the Culture Collection of the Laboratorio de Biotecnología Molecular of the InBioMis. Because of these reasons, the fungus was explored at the molecular level for the first time.

The blast search indicated that LBM 034 isolate correspond to the specie Irpex lacteus (Fr.) Fr., as it showed the highest sequence similarities to I. lacteus strain KUC8958 (JX311924.1; $97 \%$ \%), I. lacteus strain CB1 (KF318788.1; $97 \%$ ), and I. lacteus strain KUC9124 (JX290578.1; 97 \%). 

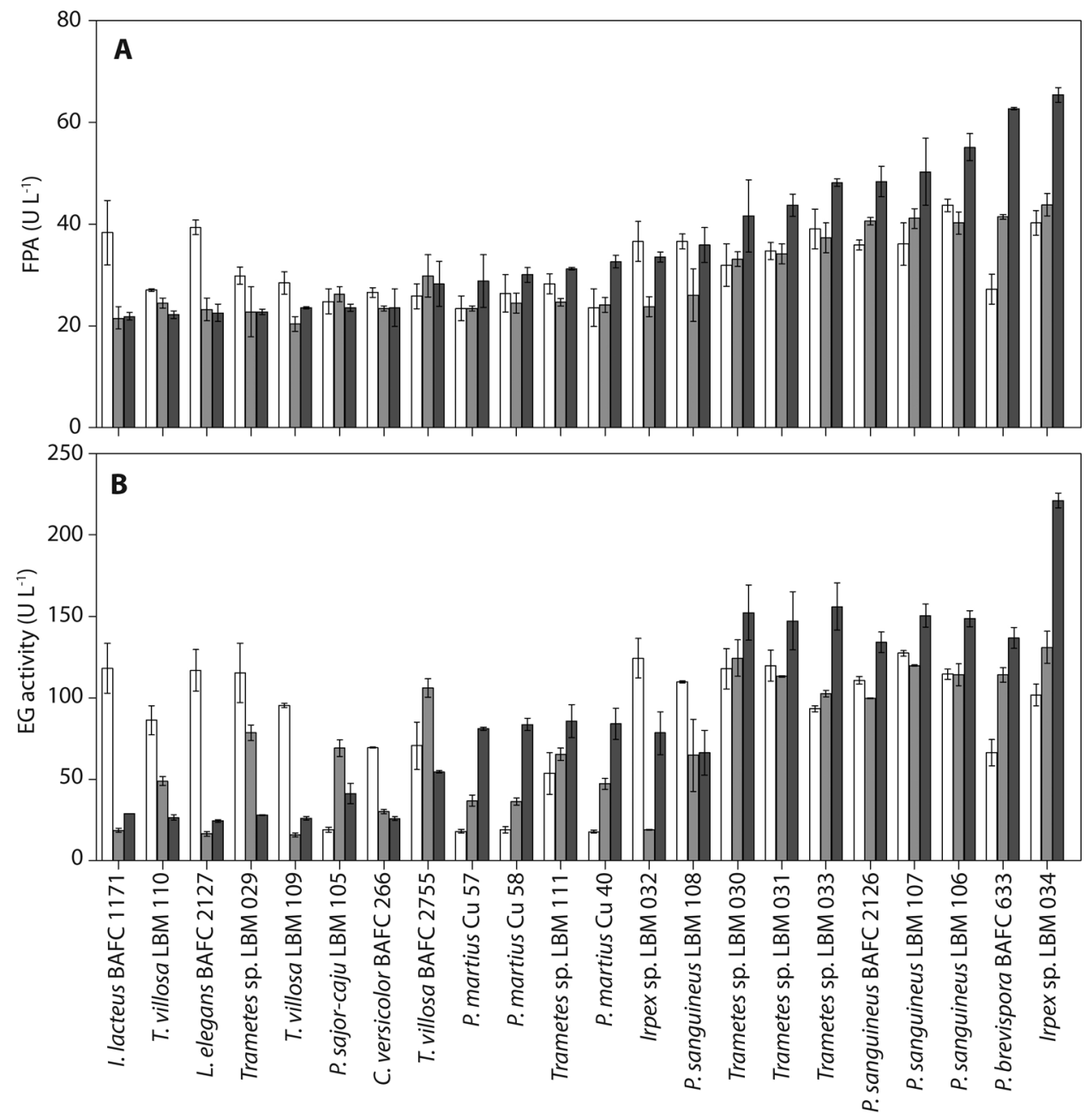

Fig. 2a. Extracellular cellulolytic activity of fungal isolates in submerged culture: Total cellulase activity (FPase). Clear $(\square)$, shadowed ( $\square$ ), and filled ( $\square$ ) bars represent 4, 9, and 14 days of incubation, respectively. Data are mean \pm SD of

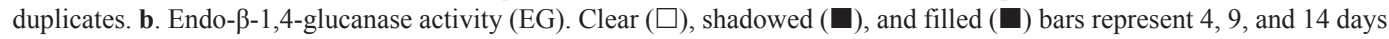
of incubation, respectively. Data are mean $\pm \mathrm{SD}$ of duplicates.

The phylogenetic tree was reconstructed by the maximum parsimony method, based on ITS1-5.8S-ITS2 rDNA region sequences. Alignment of all 38 ITS sequences from Basidiomycota yielded a consensus length of 503 characters, of which 338 (67\%) were parsimony informative. Parsimony analysis of combined nucleotide and gap data yielded a single most-parsimonious tree of 2163 steps $(\mathrm{CI}=$ 0.41 , RI $=0.58$ ). Phylogenetic tree showed that the LBM 034 isolate formed a cluster with species of I. lacteus with $100 \%$ bootstrap of branch support (Fig. 3). Therefore, the isolate selected in this study was assigned to the taxon I. lacteus.

\section{DISCUSSION}

Although the diversity of wood-decaying fungi associated to the Paranaense rainforest region has been studied (Rajchenberg \& Robledo, 2013; Gallo et al., 2014; Robledo et 


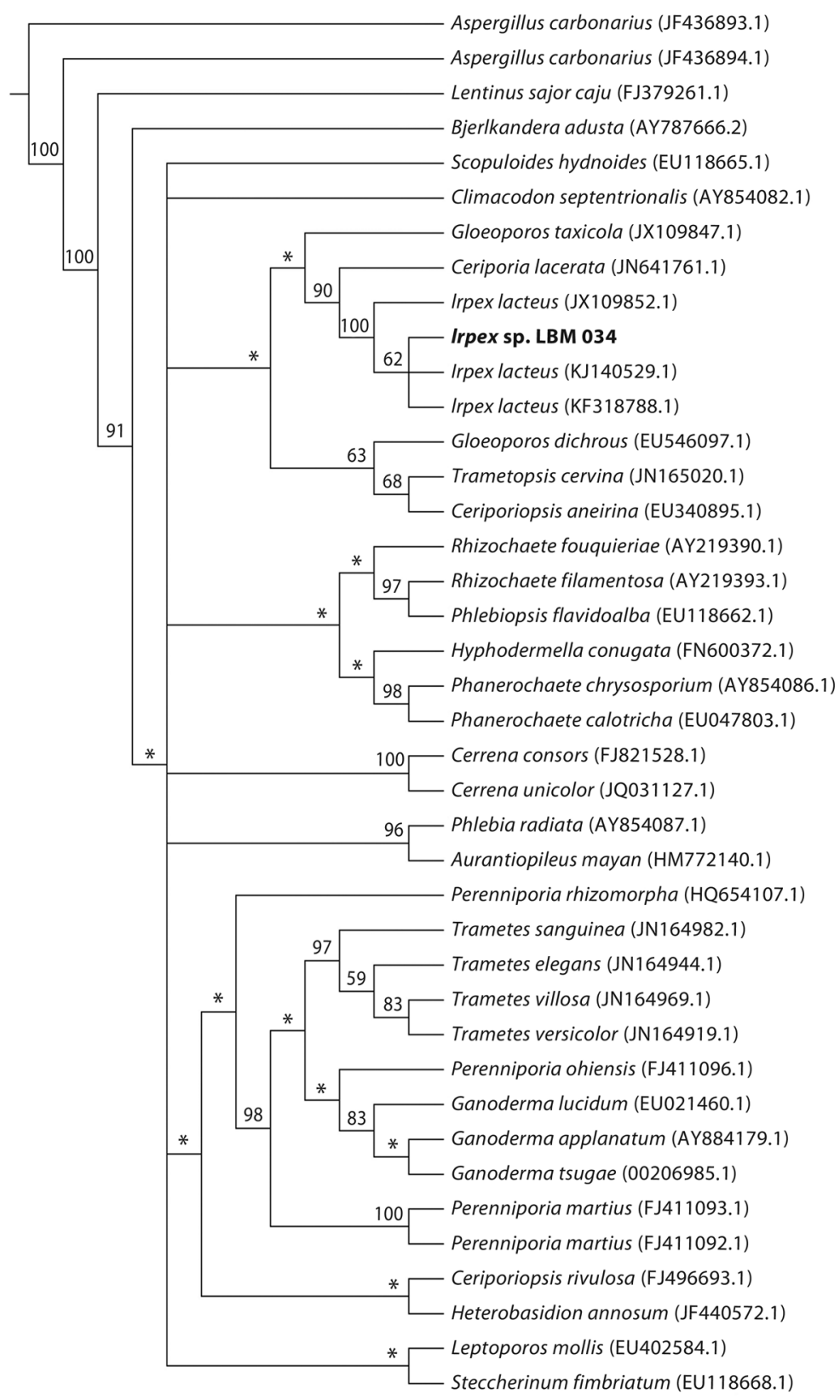

Fig. 3. Phylogenetic tree performed using maximum parsimony method based on the sequence alignment of the ITS1-5.8SITS2 of the fungus under study with homologous sequences obtained from the GenBank (NCBI). The tree was constructed with T.N.T. program. Confidence levels were obtained by bootstrapping (1 000 replicates) and indicated at each node. *Represent the collapsed branches below a cutoff of 50 . 
al., 2014), only a few researchers have explored the fungal biota of this environment, and the knowledge of cellulolytic enzyme production has been very much restricted. Therefore, the present study was carried out to analyze the cellulolytic ability of 22 white-rot fungi, isolated from woody materials collected from the subtropical rainforest of Misiones, Argentina.

First, the growing ability of filamentous fungi on agar medium supplemented either sodium carboxy-methylcellulose or crystalline cellulose as sole carbon source was scanned. Mycelia growth extension is indicative of the ability to synthesize and produce extracellular hydrolytic enzymes involved in cellulolysis, providing the nutritional requirements of these fungi of biotechnological importance (NwodoChinedu, Okochi, Smith, \& Omijidi, 2005).

All isolates showed ability to grow and degrade both substrates in spite of their different nature; one is a soluble derivative (CMC) and the other is an insoluble element (CC). Phlebia brevispora BAFC 633 isolate was the only fungus that showed the faster radial growth rate on $\mathrm{CMC}$ in comparison with $\mathrm{CC}$ medium, whereas $P$. sanguineus BAFC 2126, Trametes sp. LBM 031, Trametes sp. LBM 033, and $P$. sanguineus LBM 106 isolates showed the faster radial growth rate on $\mathrm{CC}$ in comparison with CMC medium.

Compared to our results, the Ascomycota Trichothecium roseum (Pers.) Link showed a similar radial growth rate to that $P$. brevispora BAFC 633, I. lacteus BAFC 1171, and T. villosa LBM 110. On the other hand, Shanmugam, Mani, \& Narayanasamy (2008) reported a higher growth in this fungus on a medium using CMC compared to one with cellobiose or filter paper. Kudanga \& Mewenje (2005) found a higher growth in some filamentous fungi on $\mathrm{CMC}$ medium due to the ability of CMC to act as an indirect inducer of cellulase production.

Trametes sp. LBM 033 isolate showed greater $\mathrm{CEI}$ on $\mathrm{CMC}$ medium, whereas $I$. lacteus BAFC 1171, Trametes sp. LBM 031, I. lacteus LBM 034, P. sajor-caju LBM 105, $P$. sanguineus LBM 106, P. sanguineus LBM 107, P. sanguineus LBM 108, T. villosa LBM
111, P. martius $\mathrm{Cu} 40$, P. martius $\mathrm{Cu} 57$, and P. martius $\mathrm{Cu} 58$ isolates showed greater CEI on CC medium. On the other hand, no data are available on the physiology and the cellulolytic enzymatic system of $P$. martius, being this work the first report about its ability to degrade cellulose using extracellular hydrolytic enzymes.

The differences observed according to the cellulosic sources used may be indicative of a differential ability of these isolates to produce cellulolytic enzymes, possibly involving specific mechanisms of induction (Ganner et al., 2012). However, other characteristics of the enzymes produced in the culture medium, linked to their stability and activation can lead to differences in the extent of the degradation halo observed with regard to the diameter of the fungal colony (Llacza-Ladera, 2012).

To quantitatively evaluate the cellulolytic ability of the 22 isolates, they were scanned for the production of two extracellular hydrolytic enzymes under submerged fermentation.

The reduction in levels of cellulolytic enzyme activity increasing incubation time in some isolates could be attributed to several reasons such as the production and activity of proteases during growth (Ohnishi, Yoshida, \& Sekiguchi, 1994), the acidification of the medium according to culture time (Gao \& Breuil, 1995) and the low stability of cellulases (Janusz, Rogalski, Barwińska, \& Szczodrak, 2006). However, it was found that only the Irpex sp. LBM 034 isolate showed a high cellulase activity towards filter paper and CMC substrates with increasing incubation time. Enzymatic activity values of Irpex sp. LBM 034 are higher than those previously reported by Llacza-Ladera (2012) in species of Paecilomyces sp. (48 $\left.\mathrm{U} \mathrm{L}^{-1}\right)$ and Aspergillus sp. (48 $\left.\mathrm{U} \mathrm{L}^{-1}\right)$. However, results here are somewhat lower than those reported by Vilches (2002) in species of Chrysosporium sp., and Fusarium sp. with activities of 120 , and $112 \mathrm{U} \mathrm{L}^{-1}$, respectively. The difference of values obtained in this work with the previously reported values may be explained by the differences in the test conditions, such as incubation time, substrate concentration, temperature, $\mathrm{pH}$ and others, 
which are known to have influence on cellulases production (Li et al., 2013).

The production cost of cellulolytic enzymes has declined over the last decade (Stephanopoulos, 2007), but it is still high enough to seriously affect the lignocellulosic ethanol process (Klein-Marcuschamer, Oleskowicz-Popiel, Simmons, \& Blanch, 2012). Most of the cellulolytic enzymes currently available in the market are from fungal sources. The primary industrial use of fungi is the production of enzymes and two species in particular are industrial workhorses: Trichoderma reesei E. G. Simmons and Aspergillus niger Tiegh. However, literally thousands of fungi occupy the same ecological niche as Trichoderma and Aspergillus as decomposers and recyclers of cellulosic biomass and as yet they have not been exploited commercially.

We also demonstrate that LBM 034 isolate produced high EG activity. Therefore, this isolate is a promising fungus for obtaining ethanol from cellulosic biomass.

ITS region sequences are highly used to infer phylogenetic relationships of closely related fungal species, as well as to evaluate the variability within a population and between geographically distant isolates (Hilden, Bortfeldt, Hofrichter, Hatakka, \& Lundell, 2008). Based on our phylogenetic analysis (Fig. 3), the LBM 034 isolate belongs to Irpex lacteus. Since there are previous reports about other isolates from this species (Hamada et al., 1999; 2001; Novotný, Cajthaml, Svobodová, Šušla, \& Šašek, 2009), future studies are still needed using this fungus to evaluate its potential in regional development of bioethanol production.

\section{ACKNOWLEDGMENTS}

This research was partially supported by grants from Programa de Incentivos UNaM CIDET 16Q486 (Res HCD 064/12) and the Agencia Nacional de Promoción Científica y Tecnológica (ANPCyT, PICT 2015-1620). Robledo G.L., Zapata P.D. and Saparrat M.C.N. are researchers of CONICET. Villalba L.L. and
Zapata P.D. are researchers of UNaM. Giorgio E.M. is a CONICET fellow.

\section{RESUMEN}

Capacidad celulolítica de una cepa prometedora de Irpex lacteus (Basidiomycota: Polyporales) de la selva subtropical de la provincia de Misiones, Argentina. La actividad celulolítica de hongos autóctonos asociados a la selva subtropical de Misiones (Argentina) representa un desafío en el desarrollo tecnológico de la producción de bioetanol celulósico en la región, mediante el uso de recursos nativos. Los sistemas enzimáticos de estos hongos tienen potencial aplicación en la obtención de cocteles enzimáticos rentables. La habilidad celulolítica de 22 hongos causantes de pudrición blanca se analizó comparativamente, que fueron aislados de la selva subtropical de Misiones-Argentina, en cultivos agarizados con dos tipos de sustratos celulósicos, carboxi-metilcelulosa o celulosa cristalina. También se evaluó la actividad de dos enzimas celulolíticas en cultivos líquidos. Aunque todos los aislamientos fueron capaces de crecer y degradar ambos sustratos en medio agarizado y revelar actividad celulolítica total y endo- $\beta$-1,4-glucanasa en cultivo líquido, el aislamiento Irpex sp. LBM 034 mostró las mayores actividades en papel de filtro con $65.45 \mathrm{U} \mathrm{L}^{-1}$ y endo- $\beta-1,4-$ glucanasa con $221.21 \mathrm{U} \mathrm{L}^{-1}$, respectivamente. Por tanto, se secuenció y analizó la secuencia ITS de este hongo a través de un análisis filogenético. Estos resultados indicaron que el aislamiento LBM 034, correspondiente a Irpex lacteus, tiene una habilidad celulolítica prometedora en la producción de enzimas con actividad endo- $\beta$-1,4-glucanasa, útil en la sacarificación sustentable de materiales celulósicos de la región.

Palabras clave: hongos de pudrición blanca; Irpex lacteus; FPase; endo- $\beta$-1; 4-glucanasa.

\section{REFERENCES}

Akiba, S., Kimura, Y., Yamamoto, K., \& Kumagai, H. (1995). Purification and characterization of a protease-resistant cellulase from Aspergillus niger. Journal of Fermentation and Bioengineering, 79(2), 125-130.

Altschul, S. F., Madden, T. L., Schäffer, A. A., Zhang, J., Zhang, Z., Miller, W., \& Lipman, D. J. (1997). Gapped BLAST and PSI-BLAST: a new generation of protein database search programs. Nucleic Acids Research, 25(17), 3389-3402.

Andrino, A., Morte, A., \& Honrubia, M. (2011). Caracterización y cultivo de tres cepas de Pleurotus eryngii (Fries) Quélet sobre sustratos basados en residuos agro-alimentarios. Anales de Biología, 33, 53-66. 
Brown, A. D., Grau, A., Lomáscolo, T., \& Gasparri, N. I. (2002). Una estrategia de conservación para las selvas subtropicales de montaña (Yungas) de Argentina. Ecotrópicos, 15(2), 147-159.

Cabrera, A. L. (1994). Enciclopedia Argentina de Agricultura y Jardinería. Fascículo 1. Regiones Fitogeográficas Argentinas. Buenos Aires: Editorial Acme.

Daâssi, D., Zouari-Mechichi, H., Belbahri, L., Barriuso, J., Martínez, M. J., Nasri, M., \& Mechichi, T. (2016). Phylogenetic and metabolic diversity of Tunisian forest wood-degrading fungi: a wealth of novelties and opportunities for biotechnology. Biotechnology, 6(46), 1-16.

Fonseca, M. I., Tejerina, M. R., Sawostjanik-Afanasiuk, S. S., Giorgio, E. M., Barchuk, M. L., Villalba, L. L., \& Zapata, P. D. (2016). Preliminary studies of new strains of Trametes sp. from Argentina for laccase production ability. Brazilian Journal of Microbiology, 47, 287-287.

Gallo, M. C., Robledo, G., Romero, A. I., \& Catania, M. (2014). New records of Ascomycota in the Northwestern Argentinean Yungas. Checklist, 10(3), 621-631.

Ganner, T., Bubner, P., Eibinger M., Mayrhofer, C., Plank, H., \& Nidetzky, B. (2012). Dissecting and reconstructing synergism in situ visualization of cooperativity among cellulases. Journal of Biological Chemistry, 287(52), 43215-43222.

Gao, Y., \& Breuil, C. (1995). Extracellular lipase production by a sapwood-staining fungus Ophiostoma piceae. World Journal of Microbiology and Biotechnology, 11, 638-642.

Ghose, T. (1987). Measurement of cellulase activities. Pure and Applied Chemistry, 59, 257-268.

Giorgio, E. M., Fonseca, M. I., Tejerina, M. R., RamosHryb, A. B., Sanabria, N., Zapata, P. D., \& Villalba, L. L. (2012). Chips and sawdust substrates application for lignocellulolytic enzymes production by solid state fermentation. International Research Journal of Biotechnology, 3(7), 120-127.

Goloboff, P. A., Farris, J. S., \& Nixon, K. C. (2008). TNT, a free program for phylogenetic analysis. Cladistics, 24, 774-786.

Guigón-López, C., Guerrero-Prieto, V., Vargas-Albores, F., Carvajal-Millán, E., Ávila-Quezada, G. D., Bravo-Luna, L., ... Lorito, M. (2010). Identificación molecular de cepas nativas de Trichoderma spp., su tasa de crecimiento in vitro y antagonismo. Revista Mexicana de Fitopatología, 28(2), 87-96.

Habibi, Y., Lucia, L. A., \& Rojas, O. J. (2010). Cellulose nanocrystals: Chemistry, selfassembly, and applications. Chemical Reviews, 110(6), 3479-3500.
Hamada, N., Ishikawa, K., Fuse, N., Kodaira, R., Shimosaka, M., Amano, Y., Kanda, T., \& Okazaki, M. (1999). Purification, characterization and gene analysis of exo-cellulase II (Ex-2) from the white rot basidiomycete Irpex lacteus. Journal of Bioscience and Bioengineering, 87, 442-451.

Hamada, N., Kodaira, R., Nogawa, M., Shinji, K., Ito, R., Amano, Y., ... Okazaki, M. (2001). Role of cellulose binding domain of exocellulase I from white rot basidiomycete Irpex lacteus. Journal of Bioscience and Bioengineering, 91, 359-362.

Hilden, K. S., Bortfeldt, R., Hofrichter, M., Hatakka, A., \& Lundell, T. K. (2008). Molecular characterization of the basidiomycete isolate Nematoloma frowardii b19 and its manganese peroxidase places the fungus in the corticioid genus Phlebia. Microbiology, 154, 2371-2379.

Janusz, G., Rogalski, J., Barwińska, M., \& Szczodrak, J. (2006). Effects of culture conditions on production of extracellular laccase by Rhizoctonia praticola. Polish Journal of Microbiology, 55, 309-19.

King, B., Donnelly, M., Bergstrom, G., Walker, L. P., \& Gibson, D. (2008). An optimized microplate assay system for quantitative evaluation of plant cell wall degrading enzyme activity of fungal culture extracts. Biotechnology and Bioengineering, 102, 1033-1043.

Klein-Marcuschamer, D., Oleskowicz-Popiel, P., Simmons, B. A., \& Blanch, H. W. (2012). The challenge of enzyme cost in the production of lignocellulosic biofuels. Biotechnology and Bioengineering, 109, 1083-1087.

Kudanga, T., \& Mwenje, E. (2005). Extracellular cellulase production by tropical isolates of Aureobasidium pullulans. Canadian Journal of Microbiology, 51, 773-776.

Li, C., Yang, Z., Zhang, R. H. C., Zhang, D., Chen, S., \& Ma, L. (2013). Effect of $\mathrm{pH}$ on cellulase production and morphology of Trichoderma reesei and the application in cellulosic material hydrolysis, Journal of Biotechnology, 168(4), 470-477.

Llacza-Ladera, H. F. (2012). Evaluación de la actividad celulolítica del complejo enzimático celulasa en cepas fúngicas de los departamentos de Cajamarca, Lima, Junín, Huánuco. (Tesis para optar al Título Profesional de Biólogo - Microbiólogo - Parasitólogo). Facultad de Ciencias Biológicas. E.A.P. de Microbiología y Parasitología. Universidad Nacional Mayor de San Marcos.

Lynd, L. R., Weimer, P. J., van Zyl, W. H., \& Pretorius, I. S. (2002). Microbial cellulose utilization: fundamentals and biotechnology. Microbiology and Molecular Biology Reviews, 66(3), 506-577.

Mangelli, P., \& Forchiassin, F. (1999). Regulation of the cellulase complex production by Saccobolus 
saccaboloides, induction and repression by carbohydrates. Mycologia, 91(2), 359-364.

Martínez, A. E., Chiocchio, V. M., \& Godeas, A. M. (2001). Hyphomycetes celulíticos en suelos de bosques de Nothofagus, Tierra del Fuego. Gayana Botánica, 58(2), 123-132.

Miller, G.L. (1959). Use of dinitrosalicylic acid reagent for determination of reducing sugar. Analytical Chemistry, 31, 426-428.

Niveiro, N., Popoff, O. F., \& Albertó, E. O. (2010). Contribución al conocimiento de los Agaricales s.l. de la Selva Paraneaense Argentina. Boletín de la Sociedad Argentina de Botánica, 45(1-2), 17-27.

Novotný, Č., Cajthaml, T., Svobodová, K., Šušla, M., \& Šašek, V. (2009). White-rot fungus with biotechnological potential - review. Folia Microbiologica, 54(5), 375-390.

Nwodo-Chinedu, S., Okochi, V. I., Smith, H. A., \& Omijidi, O. (2005). Isolation of cellulolytic microfungi involved in wood-waste decomposition: prospects for enzymatic hydrolysis of cellulosic wastes. International Journal of Biomedical and Health Sciences, 1(2), 41-45.

Ohnishi, K., Yoshida, Y., \& Sekiguchi, J. (1994). Lipase production of Aspergillus oryzae. Journal of Fermentation and Bioengineering, 77, 490-495.

Rajchenberg, M., \& Robledo, G. (2013). Pathogenic Polypores in Argentina. Forest Pathology, 43(3), 171-184.

Robledo, G., Giorgio, E. M., Franco, C. R. P., Popoff, O., \& Decock, C. (2014). Gyrodontium sacchari (Spreng.) Hjortstam (Boletales, Basidiomycota) in America: new records and its geographic distribution. Checklist, 10(6), 1514-1519.

Saparrat, M. C. N., Martínez, M. J., Cabello, M. N., \& Arambarri, A. M. (2002). Screening for ligninolytic enzymes in autochthonous fungal strains from Argentina isolated from different substrata. Revista Iberoamericana de Micología, 19, 181-185.

Shanmugam, P., Mani, M., \& Narayanasamy, M. (2008). Biosynthesis of cellulolytic enzymes by Trichothecium roseum with citric acid mediated induction. African Journal of Biotechnology, 7(21), 3917-3921.

Siddiqui, K. S., Shemsi, A. M., Anwar, M. A., Rashid, M. H., \& Rajoka, M. I. (1999). Partial and complete alteration of surface charges of carboxy-methylcellulase by chemical modification: thermostabilization in watermiscible organic solvent. Enzyme and Microbial Technology, 24(8-9), 599-608.

Sistema Argentino de Información Jurídica. (2012). Decreto reglamentario de la ley XVI - NRO. 106 que instituye el marco regulatorio de los recursos dendroenergéticos renovables en el ámbito de la provincia de Misiones. Recuperado de http://www.saij.gob. ar/1226-local-misiones-decreto-reglamentario-leyxvi-nro-106-instituye-marco-regulatorio-recursosdendroenergeticos-renovables-ambito-provincia-misiones-n20120001226-2012-08-24/1234567890abc-622-1000-2102nvorpced

Siqueira, G., Bras, J., \& Dufresne, A. (2010). Cellulosic bionanocomposites: A review of preparation, properties and applications. Polymers, 2(4), 728-765.

Stephanopoulos, G. (2007). Challenges in engineering microbes for biofuels production. Science, 315, 801-804.

Tekere, M., Mswaka, A. Y., Zvauya, R., \& Read, J. S. (2001). Growth, dye degradation and ligninolytic activity studies on Zimbabwean white rot fungi. Enzyme and Microbial Technology, 28(4-5), 420-426.

Teza, V. G., Fonseca, M. I., Walantus, L. H., Davalos, P., Toro, A. A, Cariaga-Martinez, A. ... Zapata, P. D. (2012). Estandarización de marcadores moleculares microsatélites para su uso en la industria forestal de Misiones, Argentina. Revista Colombiana de Biotecnologia, 14(1), 216-223.

Vilches, P. L. (2002). Determinación de la actividad de exoglucanasas de cepas fúngicas nativas de las provincias de Huaylas y Huaraz. (Tesis de grado) Facultad de Ciencias Biológicas. Universidad Nacional Mayor de San Marcos. Lima, Perú.

White, T. J., Bruns, T., Lee, S., \& Taylor, J. (1990). Amplification and direct sequencing of fungal ribosomal RNA genes for phylogenetics. In M. A. Innis, D. H. Gelfand, J. J. Sminsky, \& T. J. White (Eds.). PCR Protocols: A guide to methods and applications (315322). New York, USA: Academic Press, Inc.

Wright, J. E., Lechner, B. E., \& Popoff, O. F. (2008). Atlas pictórico del Parque Nacional Iguazú. Buenos Aires: L.O.L.A.

Zuloaga, F. O., Morrone, O., \& Rodríguez, D. (1999). Análisis de la biodiversidad en plantas vasculares de la Argentina. Kurtziana, 27(1), 17-167. 